\title{
Accreditation of educational activities in the aspect of international quality assurance standards
}

\author{
Timur Tabishev* \\ Kabardino-Balkarian State University named after H.M. Berbekov, Nalchik, Russia.
}

\begin{abstract}
The article considers the peculiarities of the Russian national educational space and legislation in the aspect of international (European) standards of quality assurance of higher education ESG (European Standards and Guidelines). The official materials and statistical data of the Executive Agency for Educational and Cultural Programs of the European Commission, given in the final report on the realization and implementation of the principles of the Bologna Process "The European Higher Education Area in 2018", are analyzed. The main points where the procedures of the Russian state accreditation of educational activities in accordance with the requirements of the Federal State Educational Standards of Higher Education (FSES HE) and the European international (professional-public) accreditation of standards and recommendations for quality assurance of higher education in the European space ESG are reflected and their main distinguishing features are indicated.
\end{abstract}

The introduction of new updated federal state educational standards for higher education (the so-called FSES HE 3++ standards) requires an innovative approach to the formation of systems for assessing the quality of education in all its manifestations: educational activities, educational process, educational systems and technologies, the level of competence. It is also important to ensure the orientation of higher education to the dynamic competence and qualification model of the future graduate $[1,2,3]$, the introduction of diverse technologies of control and evaluation [4], the use of mechanisms of cross-border education and internationalization $[5,6]$.

The objective right of participants in the educational process to design and apply in their activities a variety of approaches to quality assessment systems of higher education is enshrined in the Federal Law «On Education in the Russian Federation» (hereinafter - the Federal Law) [7]. Chapter 12 of the Federal Law contains possible forms, methods, technologies and mechanisms of state and professional-public regulation of educational activity. The state regulation of educational activity consists in providing unified requirements for the organization and implementation of educational activities, as well as tracking the implementation of these requirements by educational organizations. In accordance with article 90 of the Federal Law, the state regulation of educational activity

\footnotetext{
* Corresponding author: timur.tabishev@yandex.ru
} 
includes interrelated procedures: licensing, state accreditation and state control (supervision) in the field of education.

Whereas in the previous law on education the possibility of using mechanisms of nonstate regulation of the quality of education, including elements of cross-border education and international accreditation procedures, were fixed only as one paragraph in the section «State accreditation of educational institutions, scientific organizations», in the Federal law their deployment is made with the reflection of common methodological, technological, information and other characteristics and features. Some items cover such mechanisms of professional and public regulation of educational activities as independent assessment of the quality of education, public accreditation, international and professional accreditation of educational programs.

The latest version of the Federal State Educational Standards for Higher Education (hereinafter - FSES HE) takes a very urgent step in uniting the competence and qualification aspects of the graduate model. Now, in addition to the state attributes of the regulation of educational activities (requirements for the structure of the educational program, the list of universal and general professional competencies, material and technical support of educational activities, financial conditions for the implementation of the educational program), FSES HE establishes the requirements for the applied mechanisms for assessing the quality of educational activities and training of students in the implemented educational programs, fixes the inalienable right of presence on the images.

Also, FSES HE in the requirements to the applied mechanisms of assessment of the quality of educational activities and training of students determines the right to carry out the examination of educational programs within the framework of professional-public accreditation in order to recognize the quality and level of training of graduates meeting the requirements of professional standards, the requirements of the employment market to specialists in the relevant field. Such expertise is carried out by employers, their associations, as well as by authorized organizations, including foreign ones, or authorized national professional and public organizations included in international structures. In addition, the FSES HE contains an annex that defines the list of professional standards corresponding to the professional activities of graduates, which indicates the range of stakeholders in educational relations.

It should be noted that the procedures of state regulation of educational activities in their assessment are more focused on the «competence» side of the graduate model (on the levels of competence formation), and the mechanisms of professional-public regulation of educational activities - on the «qualification» side (on the levels of professional training). This is where the fundamentally different methods and technologies in carrying out these procedures are manifested (Fig. 1). But this determines the literacy and efficiency of building quality assessment systems for higher education, cultivating both approaches.

If, for example, the purpose of state accreditation of educational activities is to confirm the conformity of FSES HE on the implemented educational programs, the purpose of international (professional-public) accreditation is the recognition by employers and their associations (including foreign or Russian organizations that are members of international structures) of the quality and level of training of graduates who have mastered the educational program, meeting the requirements of professional standards and the employment market to specialists in the relevant field in accordance with independently established and/or international quality standards for higher education. And only the unity of these approaches reflects the quality content and, importantly, the competitiveness of the educational programme and the educational process in the Russian and international educational space.

Let's consider the moments when the procedures of state accreditation of educational activity in accordance with the requirements of FSES HE and professional-public (international) accreditation according to the European standards ESG, developed by the 
European Network for Quality Assurance (ENQA) for the countries that signed the Bologna Declaration [9] overlap and their main distinguishing features.

First of all, it should be noted that the ideology of state and professional-public accreditation procedures is somewhat different. They overlap in the fundamental blocks each procedure is based on a set of specific rules and requirements - the standard. Requirements of state accreditation are mandatory for all participants of educational relations (we consider only educational organizations implementing educational programs in accordance with FSES HE), and ESG standards have a recommendatory character and are a kind of reference guide.

Secondly, the effective aspect of these procedures differs, if we talk about them as two types of accreditation. If the result of the state accreditation of educational activity is reporting (expert report and conclusion of the expert group with indication of revealed violations and comments) and conclusion on compliance or non-compliance with the requirements of FSES HE (slice of the state at the time of accreditation procedures), the professional-public accreditation is focused on reporting (conclusion of the external expert group) and a set of recommendations and further ways to improve. However, if the state accreditation is considered within the framework of the state regulation of educational activities and the existing regulatory framework, it cannot give recommendations, as the procedures of control and supervision activities (which are also included in the procedures of state regulation of educational activities) are focused on it. Nevertheless, the conclusion of the accreditation expertise reflects the revealed violations, which is a certain motivational aspect in the further improvement of educational activities of the object of expertise. Undoubtedly, as well as any objective procedures of external evaluation, these types of accreditation contribute to the improvement of the quality of educational program, form confidence in the educational organization in the future by the state and professional communities.

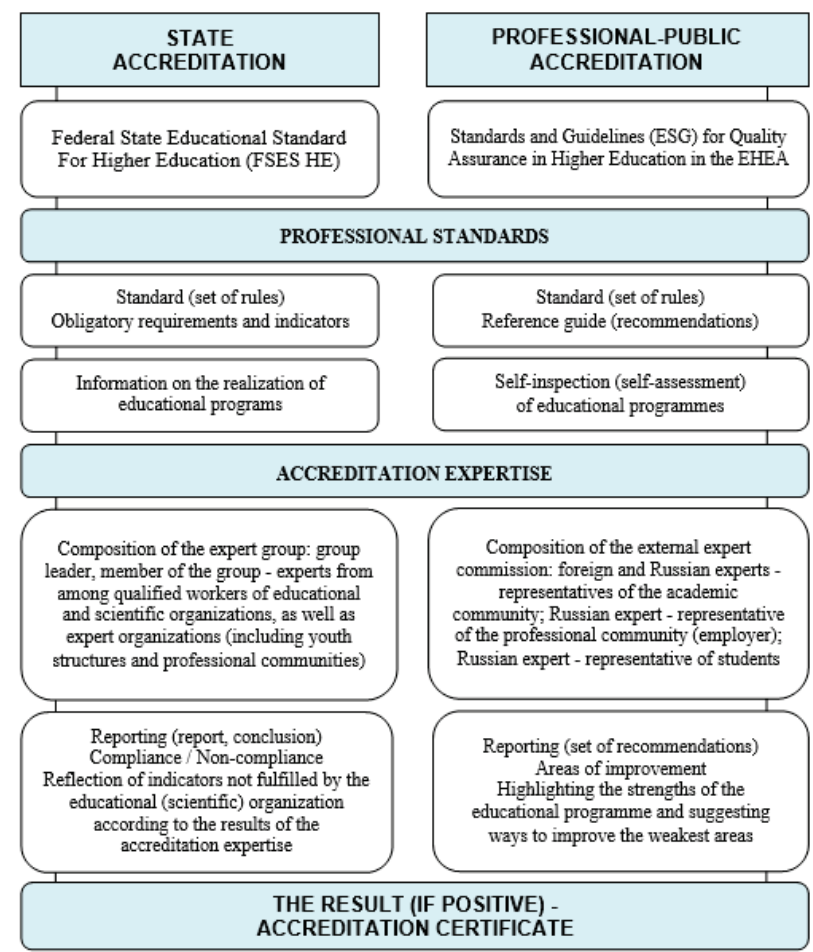

Fig. 1. Features of state and international (professional-public) accreditation of educational activities. 
It should be noted that recently objective attempts and effective steps to bring these procedures and methods of accreditation examinations closer together are clearly visible. This is largely due to several reasons. The most global of them is the export of Russian education, understanding by this not only the purely economic, but also the political essence. As one of the most important socio-cultural and geopolitical structures, universities play a very important role in promoting the prestige and influence of the Russian Federation in the international arena. It is in universities that the future world politics is born, because acquaintance, communication and friendship of the youth elite of different countries is bound to turn into interstate social and economic cooperation. And logically, the export of education asks for the accompanying mechanism of cross-border development and deployment internationalization of higher education, which is the next objective reason for the integration of elements of standards and recommendations of the ESG in the state accreditation procedures.

Almost every state has its own educational mentality and policy for the formation of quality assurance systems for vocational education. In the report of the Executive Agency for Educational and Cultural Programmes of the European Commission «The European Higher Education Area in 2018» some points and peculiarities that distinguish the Russian legislation in terms of provision of the state service of state accreditation of educational activity from the regulatory and legal regulation of other countries of the European Higher Education Area (hereinafter - EHEA) are reflected [10].

The main difference between the Russian education system and the systems of the vast majority of EHEA countries (except for Slovakia, Macedonia and Liechtenstein) is the responsibility of the state for proper quality assurance of education.

Nevertheless, in the Russian Federation there is a register of organizations providing services for international (professional-public) accreditation of higher education programmes based on ESG standards and recommendations. Moreover, there are two quality assurance agencies registered in the EQAR system (The European Quality Assurance Register for Higher Education): National Centre for Public Accreditation and Agency for Quality Assurance in Higher Education and Career Development. Currently, the National Accreditation Agency for Education is accrediting at ENQA and registering at EQAR.

In the procedures of various types of accreditation in Russia are used almost all indicators and criteria of assessment and quality assurance of educational activities, correlated with ESG, which is confirmed by the data of the European Commission in the report on the implementation of the Bologna process. The following elements of ESG were used for the analysis of these data: admission procedures, employment indicators, development and implementation of educational programs, student-centered and practice-oriented training, staffing of educational activities, methods of organization of professional development of scientific and pedagogical staff, information management and educational and methodical resources. However, there are a number of characteristics of ESG standards and recommendations, which are not integrated into the systems of state quality assurance of education in Russia, but, incidentally, are integrated into the procedures of international professional and public accreditation.

One of such parameters is the participation of students (trainees) in the procedures of external evaluation of the quality of education. According to the data of the European Commission, the Russian Federation is not quite «open and transparent» on this issue and the information in the report is not presented. It should be noted that both in the procedures of state accreditation and in the mechanisms of international professional and public accreditation students are represented to a greater extent, and to a lesser extent. Within the framework of the state accreditation, it is participation of representatives of the All-Russian public organization «Russian Union of Youth» in the procedures of accreditation expertise in specific specialties and areas of training. Within the framework of international 
accreditation, the participation of students' representatives is observed to a greater extent, as it is required by legal acts and procedural regulations.

The data of the European Commission on the results of the survey on the involvement of student activists in the procedures of external evaluation of the quality of educational activities are noteworthy. The Russian Federation is presented as a country where students' representatives take part in external quality assessment activities, but this requirement is not a prerequisite for the entire national system of education quality assurance.

However, according to the results of the European Commission's report, a significant number of countries are «not green», and there is still much to be done to implement the Bologna Process points on the comprehensive involvement of students in the processes of external evaluation of the quality of education, as well as the standards and recommendations of the ESG.

Another important aspect of ESG external quality assurance is the participation of representatives of professional communities and relevant organizations (hereinafter employers) in accreditation examinations of the quality of educational programmes (Fig. 2) [10]. This position is not integrated into the national educational system of the Russian Federation in terms of state accreditation of educational activities (or other procedures of state quality assurance), but is actively used within the framework of international (professional-public) accreditation.

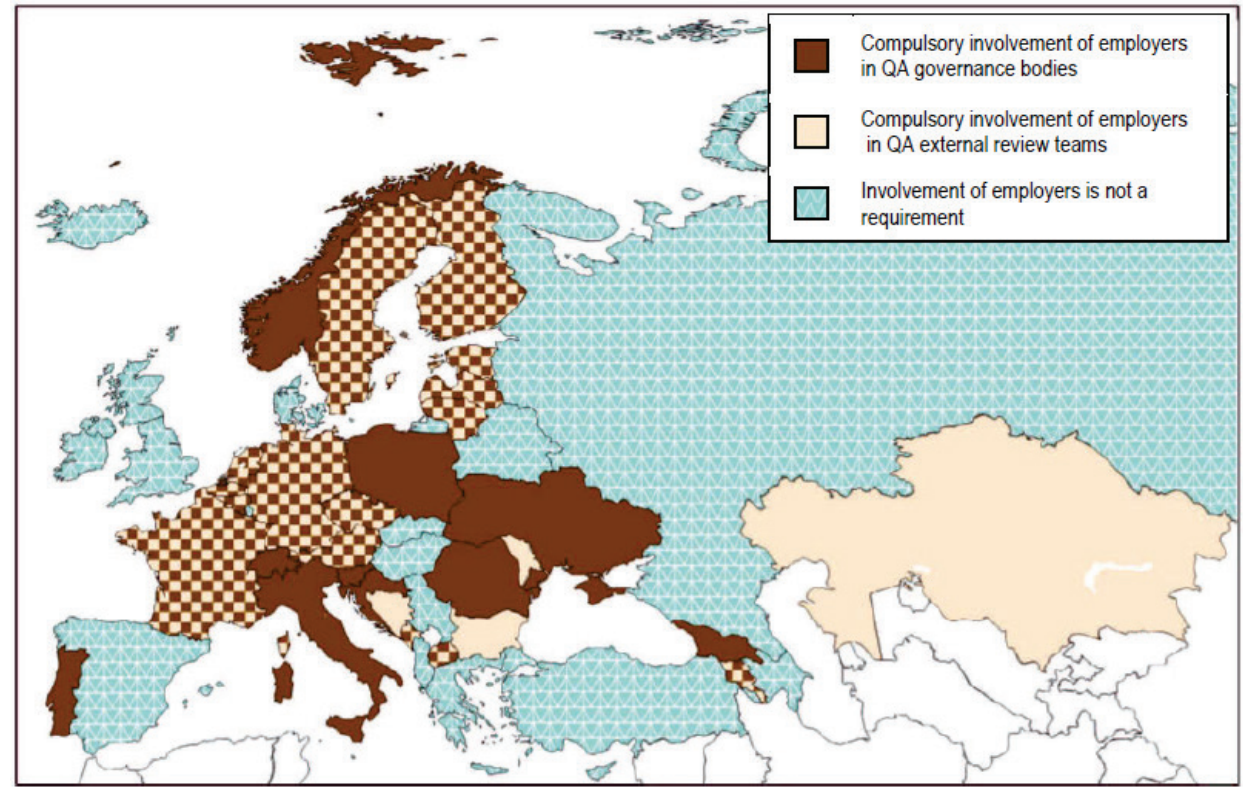

Fig. 2. Participation of employers in external quality assessment procedures.

It should be taken into account that the European Commission's data on students and employers were based on the premise that these categories of participants in educational relations should be included in the composition of external expert committees. The Russian educational system in the state regulation of educational activities in detail describes the mandatory participation of both students and employers in the procedures of internal quality assessment, at all stages of development and implementation of the educational program. For example, students have the right to determine their individual trajectory through the selection of disciplines (modules), places of practice, and representatives of employers and professional communities participate in the implementation of the educational program from the moment of its development. Since these requirements are enshrined in the FSES HE, and the purpose of state accreditation of educational activities is to confirm compliance with 
them, their implementation for educational institutions of higher education is mandatory and subject to verification during the accreditation procedures.

Undoubtedly, each national system of education quality assessment is unique. The established traditions, social patterns and legal and regulatory framework form their own point of view of each state and structures responsible for the construction of such systems, leaves an individual imprint. However, each system retains its national peculiarities and uses in its methods and technologies the points of international standards ESG. Moreover, such integration is taking place more and more.

\section{References}

1. D. Bravenboer, S. Lester, Educ. Training 4(58), 409-421 (2016)

2. M. Salas Velasco, Higher Education, 1-21 (2014)

3. N.F. Efremova, Formation and assessment of competencies in education. Monograph. («Arkol», Rostov-on-Don, 2010)

4. T.A. Tabishev, XIV Forum of experts in the field of professional education, 30-37 (2018)

5. J. Knight, International higher education. 69, 4-5 (2012)

6. A.A. Muravieva, A.I. Gorilev, Integration of education. 3 (84), 310-319 (2016)

7. Federal Law «On Education in the Russian Federation» (Moscow, 2012)

8. Federal State Educational Standard for Higher Education - Bachelor's Degree in 01.03.01 Mathematics (Moscow, 2014)

9. Standards and Guidelines for Quality Assurance in The European Higher Education Area (European Commission, Brussels, 2015)

10. European Commission/EACEA/Eurydice, 2018. The European Higher Education Area in 2018: Bologna Process Implementation Report. Luxembourg: Publications Office of the European Union (European Commission, Brussels, 2018) 